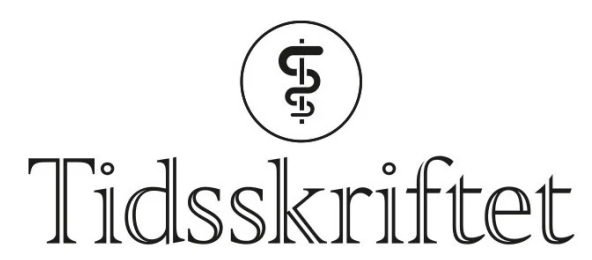

DEN NORSKE LEGEFORENING

\title{
Bly fra blodgivere: en oversett eksponeringsrute
}

FRA LABORATORIET

\section{BJØRN J. BOLANN}

bjorn.bolann@k2.uib.no Bjørn J. Bolann er spesialist i medisinsk biokjemi, professor emeritus ved Universitetet i Bergen og pensjonert overlege fra Avdeling for medisinsk biokjemi og farmakologi, Haukeland universitetssjukehus.

Forfatteren har fylt ut ICMJE-skjemaet og oppgir ingen interessekonflikter.

\section{Miljøgifter som tungmetaller og resistente organiske giftstoffer utgjør en global trussel mot både dyr og mennesker. Vi får i oss miljøgifter gjennom mat, luft og vann. At giftstoffene også kan overføres gjennom blodtransfusjon, er mindre kjent.}

Bly er et giftig tungmetall. Siden det er et grunnstoff, blir det ikke nedbrutt. Etter at blyholdig bensin ble forbudt i de fleste land, er blyinnholdet i miljøet blitt redusert, men ikke eliminert. Å helt unngå eksponering er ikke mulig.

Bly påvirker en rekke vitale biokjemiske mekanismer i blod-, nerve- og bensystem. Større eksponering kan ha dødelig utgang (1). Lavgradig eksponering kan påvirke kognitive funksjoner, særlig hos barn (르). Bly lagres i skjelettet og utskilles med lang halveringstid, opptil flere tiår. Bly i blod finnes hovedsakelig i erytrocyttene (1).

\section{Tolerabelt inntak}

Det har aldri lykkes å bestemme et trygt nivå for inntak av bly. Med ny kunnskap er nivå for tolerabelt inntak satt ned flere ganger. Den sist satte grensen for inntak av bly er på $25 \mu \mathrm{g} / \mathrm{kg}$ kroppsvekt per uke, men ifølge senere forskning finnes det ikke noen grense for trygt inntak (므). All eksponering for bly anses nå som skadelig, og skadepotensialet er størst hos de aller minste, altså spebarn.

At miljøgifter også kan overføres gjennom blodtransfusjon, er et problem som, så vidt jeg vet, ikke har vært tema i Norge. Det er imidlertid kommet flere rapporter om bekymringsverdige konsentrasjoner av tungmetall, spesielt bly, i blodgiverblod (3). 
Når vi får i oss giftstoffer gjennom maten, utgjør tarmen en beskyttelsesbarriere slik at bare en andel av stoffene absorberes. Ved intraven øs tilførsel vil denne barrieren overstyres. For bly er intestinalt opptak omkring $10 \%$ (1). . En gitt mengde bly tilført intravenøst tilsvarer derfor omtrent en 10 ganger høyere peroral tilførsel. Det betyr at en grense for tolerabel intravenøs tilførsel av bly må settes til 1/10 av grensen for peroralt inntak (3).

\section{Akseptabel konsentrasjon i blodgiverblod}

Med dette som utgangspunkt er det gjort beregninger av maksimal akseptabel konsentrasjon av bly i blodgiverblod. For blod som skal gis til premature og spedbarn er det foreslått at blyinnholdet ikke bør overstige o,09 $\mu \mathrm{mol} / \mathrm{L}(\mathrm{o}, 018 \mu \mathrm{g} / \mathrm{mL})$, eller i hvert fall ikke over $0,15 \mu \mathrm{mol} / \mathrm{L}(0,032 \mu \mathrm{g} / \mathrm{mL})$ (3). Det er vist at blynivå hos mottakere av blodgiverblod korrelerer med nivået hos giveren (4.).

I en norsk multisenterstudie hadde $18 \%$ av blodgiverne høyere blynivå enn den foreslåtte grensen for spebarn på $0,09 \mu \mathrm{mol} / \mathrm{L}$, og $4,5 \%$ hadde høyere nivå enn den alternative grensen på $0,15 \mu \mathrm{mol} / \mathrm{L}(5)$.

\section{Risikofaktorer hos blodgiverne}

Risikofaktorer for å ha et lett forhøyet blynivå i blodet er mange (1). I tillegg til mulighet for yrkesmessig eksponering finnes bly i gamle vannrør, gammel maling, keramikk, kosmetikk og smykker. Skyttere og folk som spiser mye vilt skutt med blyammunisjon er særlig utsatt (吕).

Tungmetaller i blodet stiger med alderen (5). Høy alder hos blodgiveren er derfor også en risikofaktor.

\section{Tiltak}

Å sikre at småbarn får transfundert blod med lavest mulig blyinnhold kan gjøres ved å måle blynivå hos giverne. Hittil er dette så vidt jeg vet ikke gjennomført noe sted i Norge, men gjøres enkelte steder i utlandet (7.). Det nest beste kan være å eksaminere blodgiverne om mulige risikofaktorer samt velge unge blodgivere til svært unge pasienter.

For spebarn som trenger blodtransfusjon bør man sikre at blodgiveren har lavest mulig innhold av bly i blodet. Tilsvarende gjelder for andre miljøgifter.

\section{LITTERATUR}

1. Skerfving S, Bergdahl IA, Lead I et al. Handbook of the Toxicology of Metals. 3. utg. Amsterdam: Elsevier, 2007: 599-643.

2. Jakubowski M. Low-level environmental lead exposure and intellectual impairment in childrenthe current concepts of risk assessment. Int J Occup Med Environ Health 2011; 24: 1-7. [PubMed] [CrossRef]

3. White KMR, Anderson Berry AL, White SF et al. Donor blood remains a source of heavy metal exposure. Pediatr Res 2019; 85: 4-5. [PubMed][CrossRef]

4. Takci S, Asci A, Erkekoglu P et al. Lead and mercury levels in preterm infants before and after blood transfusions. Biol Trace Elem Res 2019; 188:344-52. [PubMed][CrossRef]

5. Averina M, Hervig T, Huber $S$ et al. Environmental pollutants in blood donors: The multicentre Norwegian donor study. Transfus Med 2020;30: 201-9. [PubMed][CrossRef]

6. Green RE, Pain DJ. Risks to human health from ammunition-derived lead in Europe. Ambio 2019; 48: 954-68. [PubMed][CrossRef] 
7. New HV, Stanworth SJ, Engelfriet CP et al. Neonatal transfusions. Vox Sang 20o9; 96: 62-85. [PubMed][CrossRef]

Publisert: 2. juli 2021. Tidsskr Nor Legeforen. DOI: 10.4045/tidsskr.21.0031

(C) Tidsskrift for Den norske legeforening 2023. Lastet ned fra tidsskriftet.no 26. april 2023. 